\title{
Cities of North-West Federal District: the state of urban development sector and its main challenges
}

\author{
Olga Popova ${ }^{1}$, Marina Perekopskaya ${ }^{1,{ }^{*}}$, Kirill Grabovyy ${ }^{2}$ and Elizaveta Martynova ${ }^{1}$ \\ ${ }^{1}$ Northern Arctic Federal University named after M. V. Lomonosov, Naberezhnaya Severnoy Dviny, \\ 17, Arkhangelsk, 163002, Russia \\ ${ }^{2}$ Moscow State University of Civil Engineering, Yaroslavskoe shosse, 26, Moscow, 129337, Russia
}

\begin{abstract}
This article analyzes the compliance of planned and actual results of the implementation of the first phase of territorial planning documents of towns, medium and big cities in the North-West Federal District of Russia. Particular attention is paid to the deformation of forecasting scenario for prospective population in researched cities and to identification of factors that contributed to this deformation. The authors propose a variant of preparation of territorial planning documents in a search for effective tools for urban development of the North-West Federal District of Russia.
\end{abstract}

\section{Introduction}

After Russia's transition to a market economy and the variety of ownership forms the former system of public policy planning of socio-economic development of the country and individual territories had been destroyed. In the early 90 -s a thesis on the incompatibility of the market and planning was argued. However, it had soon become apparent that not the cancel of planning was needed, but a transition from directive to a balance of interests. It was needful to establish partnerships between different government structures and economic entities, public, which would allow municipalities the best way to adapt to the rapidly changing external environment and to realize their potential in most effective way.

The search for new quality and content of the planning of socio-economic development of cities has led to the introduction of the strategic planning system, which is widely used in foreign countries as a tool for a local development [1].

The second major subsystem of the long term urban prioritization is a territorial (urban) planning. The directions of urban development are established by law primarily in the territorial planning documents (general plan of the city) in accordance with the Urban Planning Code of the Russian Federation

The traditional object of planning in urban design is urban space, its qualitative and quantitative characteristics are: the architectural and planning organization, the spatial

\footnotetext{
${ }^{*}$ Corresponding author: mappi25@yandex.ru
} 
characteristics of industrial areas, housing sector, the public services sector, engineering infrastructure, transport infrastructure, environmental conditions [2].

The processes of strategic and urban planning are closely related. The main purpose of the strategic planning for the area socio-economic development can not be achieved without adequate spatial development framework.

At the same time the management of urban development area focused on the investment attractiveness improvement is impossible without timely strategic planning of socioeconomic development that determines the conditions of its development, the need for workforce and financial resources corresponding to its capacity and type.

In the context of asymmetrical socio-economic development intensification in certain areas, the growth of economic and social disparities the formation of the optimal mechanism for identification of investment potential of the municipality through the development of socio-economic development and the corresponding schemes of territorial planning is a top priority of local authorities for sustainable development of the territory.

In many ways design decisions of territorial planning documents are made due to scenarios of urban socio-economic development and so their implementation is made due to the accuracy of long-range forecasting.

The onset of the period indicated in the documents of territorial planning in a number of towns, medium and big cities in the North-West Federal District of Russia as the first stage of their implementation allows to evaluate compliance with the planned and actual results of the first phase of the major plans. And also this helps to identify the main forecasting scenario of social and economic development in considered interval and to indicate the factors that contributed to the deformation of these scenarios.

\section{Experimental section}

The objects of study are master plans of the cities in North-West Federal District of Russia, which have been developed and approved after the adoption of the Town Planning Code and the period of the first stage of their realization is determined for 2010-2015. According to the selection criteria among the cities of the North-West Federal District the following were selected: Arkhangelsk, Kaliningrad, Cherepovets, Petrozavodsk, Velikiy Novgorod, Pskov, Syktyvkar, Borovichi, Velikie Luki, Vyborg, Gatchina [3-13].

In the study, all the planned results of the first phase of implementation in the mentioned cities are listed with the appropriate mathematical methods to a single date January 1, 2014. Actual socio-economic indicators of the cities correspond to the specified date [14].

Table 1. Analytical data.

\begin{tabular}{|c|c|c|c|c|c|c|c|c|c|c|c|c|}
\hline \multirow[b]{3}{*}{ City } & \multirow{2}{*}{\multicolumn{3}{|c|}{ Population }} & \multicolumn{9}{|c|}{ Age structure of population } \\
\hline & & & & \multicolumn{3}{|c|}{$\begin{array}{l}\text { The proportion of } \\
\text { people under } \\
\text { working age, \% }\end{array}$} & \multicolumn{3}{|c|}{$\begin{array}{l}\text { The proportion of } \\
\text { the working } \\
\text { population, } \%\end{array}$} & \multicolumn{3}{|c|}{$\begin{array}{l}\text { The proportion of } \\
\text { people older than } \\
\text { working age, } \%\end{array}$} \\
\hline & 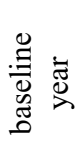 & 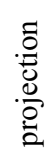 & 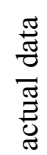 & 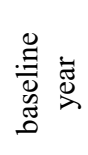 & 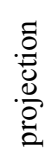 & $\frac{\text { 芜 }}{\frac{\pi}{\sigma}}$ & 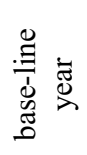 & 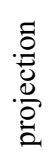 & 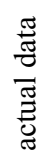 & 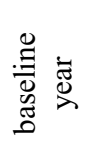 & 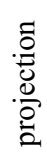 & 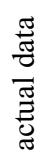 \\
\hline
\end{tabular}




\begin{tabular}{|c|c|c|c|c|c|c|c|c|c|c|c|c|}
\hline 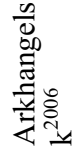 & $\begin{array}{c}349 . \\
8\end{array}$ & $\begin{array}{c}349 . \\
9\end{array}$ & $\begin{array}{c}350 . \\
4\end{array}$ & 15.3 & 15.3 & 16.2 & 66.2 & 66.2 & 60.7 & 18.5 & 18.6 & 23 \\
\hline 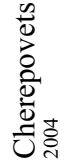 & $\begin{array}{c}310 . \\
8\end{array}$ & 304 & $\begin{array}{c}316 . \\
8\end{array}$ & 18.2 & 16.4 & 18 & 63.3 & 61 & 60 & 18.5 & 22.6 & 22 \\
\hline 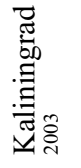 & $\begin{array}{c}427 . \\
8\end{array}$ & 480 & $\begin{array}{c}448 . \\
5\end{array}$ & 13.7 & 12.4 & 15 & 64.9 & 63.6 & 60.4 & 21.3 & 24 & 24.7 \\
\hline 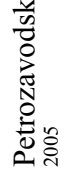 & $\begin{array}{c}266 . \\
4\end{array}$ & $\begin{array}{c}269 . \\
6\end{array}$ & $\begin{array}{c}272 . \\
1\end{array}$ & 15 & 17.2 & 15.8 & 66 & 62.5 & 61.2 & 19 & 20 & 23.0 \\
\hline$\frac{\vec{J}}{\frac{\vec{d}}{3}}$ & $\begin{array}{c}244 . \\
5\end{array}$ & $\begin{array}{c}253 . \\
7\end{array}$ & 242 & 18 & 18 & 19.5 & 67 & 67 & 66.4 & 15 & 15 & 14.1 \\
\hline 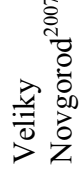 & $\begin{array}{c}216 . \\
7\end{array}$ & 232 & 220 & 20 & 20 & 15.5 & 55 & 59 & 59.7 & 25 & 21 & 24.8 \\
\hline 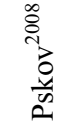 & $\begin{array}{c}194 . \\
9\end{array}$ & 190 & $\begin{array}{c}206 . \\
7\end{array}$ & 14.6 & 16 & 15.4 & 64.8 & 63 & 60.9 & 20.6 & 21 & 23.7 \\
\hline 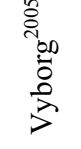 & 78.8 & 80 & 80.2 & 15.8 & 16.6 & 16.2 & 65.5 & 64.3 & 60.9 & 18.7 & 19.1 & 22.7 \\
\hline 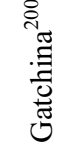 & 90.1 & 92.8 & 95.7 & 14.7 & 16.4 & 15.8 & 66.7 & 64.1 & 60.8 & 18.6 & 19.5 & 23.4 \\
\hline 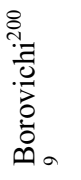 & 55.4 & 55.6 & 52.7 & 17.9 & 17.9 & 19.2 & 67.2 & 67.2 & 66.1 & 14.9 & 14.9 & 14.7 \\
\hline
\end{tabular}




\begin{tabular}{|c|c|c|c|c|c|c|c|c|c|c|c|c|}
\hline 总 & 100 & 102 & 96.5 & 18.3 & 18.3 & 19.8 & 66.5 & 66.5 & 66.7 & 15.2 & 15.2 & 13.5 \\
\hline
\end{tabular}

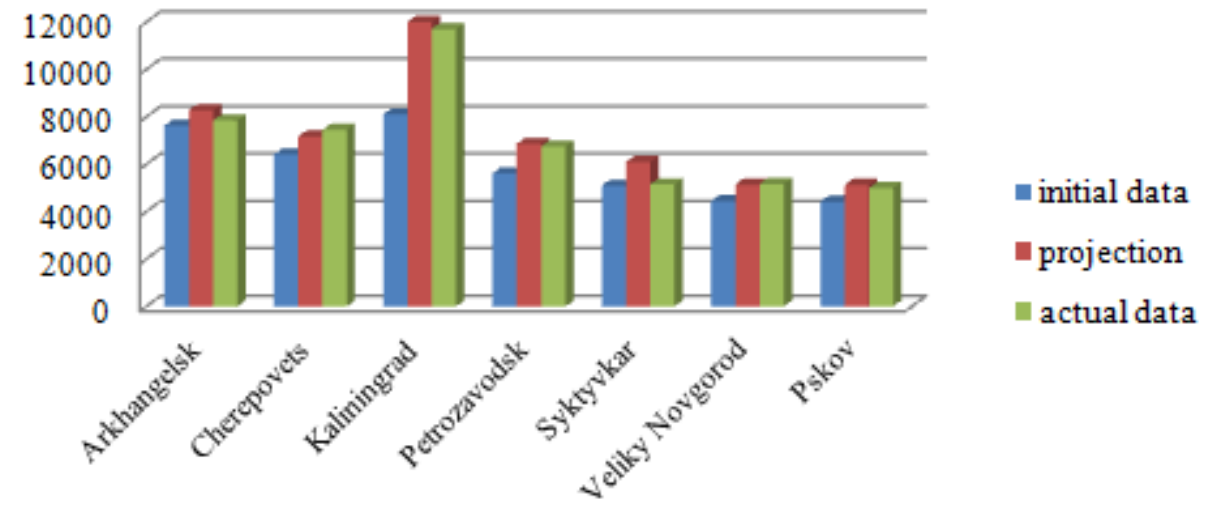

Fig. 1.1. Analytical data for the housing stock in the considered large and big cities. The total area of housing, thousand $\mathrm{m} 2$.

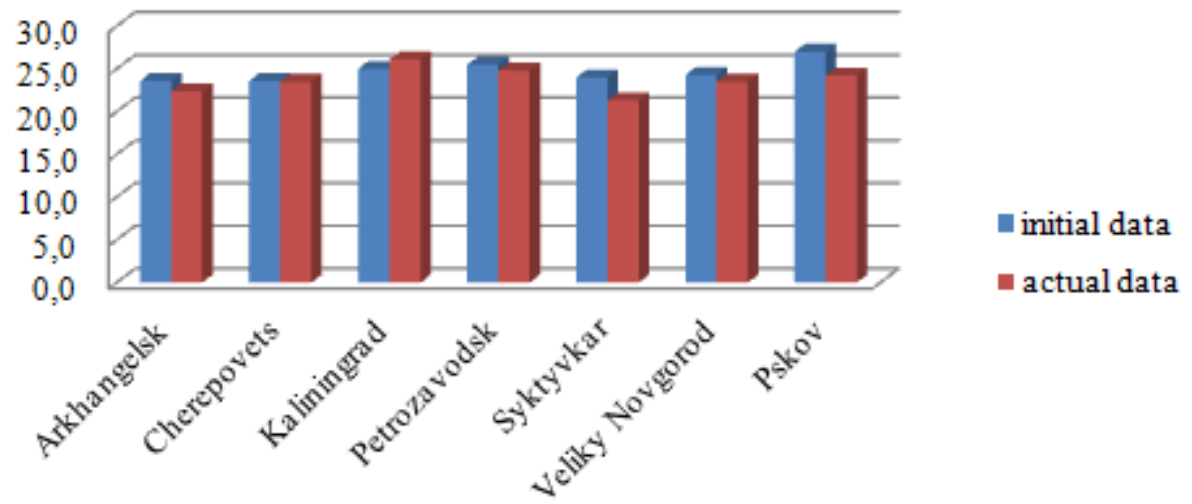

Fig. 1.2. Analytical data for the housing stock in the considered large and big cities. Norm security $\mathrm{m} 2 /$ person.

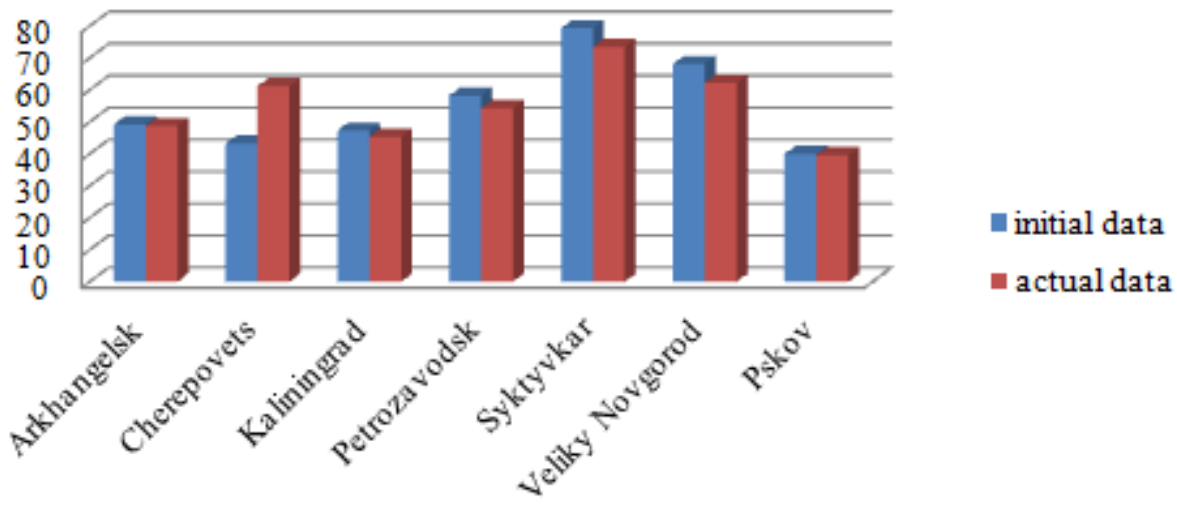

Fig. 2.1. Analytical data for the social infrastructure in the considered large and big cities. The number of places avaliable in kindergartens per 1000 reople. 


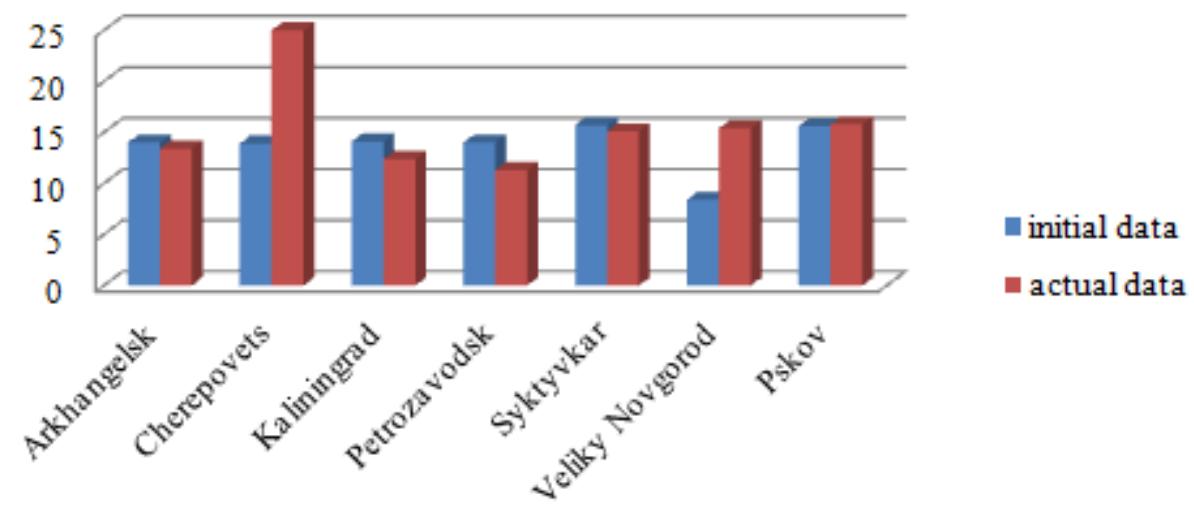

Fig. 2.2. Analytical data for the social infrastructure in the considered large and big cities. The number of hospital beds per 1000 people.

The priorities in the preparation of spatial planning documents are the creation of highquality architecture and a comfortable human environment [15]. Master Plan as the document contains design solutions made due to the results of analysis of the socioeconomic and demographic conditions of the territory. Therefore, the indicator "prospective population" was taken while identifying the main deformation of forecasting scenarios for socio-economic urban development.

\section{Results and discussion sections}

The study identified four different deformation of forecasting scenarios for prospective population:

1. Forecasting rates of population growth are 1,5-2 times less than the actual ones (Arkhangelsk, Petrozavodsk, Vyborg, Gatchina).

2. Forecasting rates of population decline are on average by $2 \%$ at actual growth of $4 \%$ (Cherepovets, Pskov).

3. Forecasting rates of population growth are 2-3 times more than the actual ones (Kaliningrad, Novgorod).

4. Forecasting rates of population growth are on average by $2 \%$ at actual decline of $3 \%$ (Syktyvkar, Borovichi, Velikie Luki).

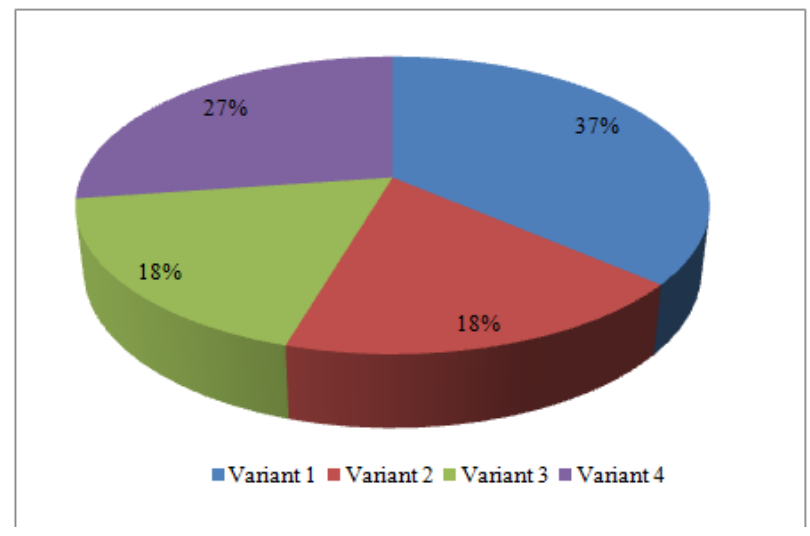

Fig. 3. Variants of deformation the forecasting scenario. 
Prospective population calculations for these groups of on the basis of component and advancing age methods [16] are based on the lowest forecast variants of the working-age population.

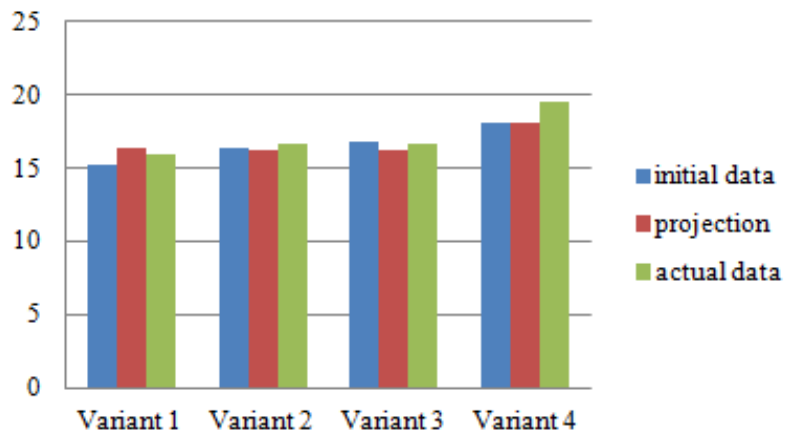

Fig. 4.1. Assessment of population structure. The proportion of people under working age.

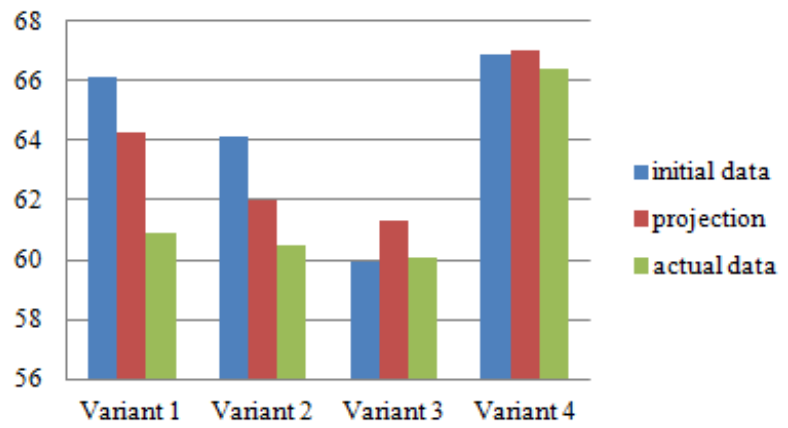

Fig. 4.2. Assessment of population structure. The proportion of working population.

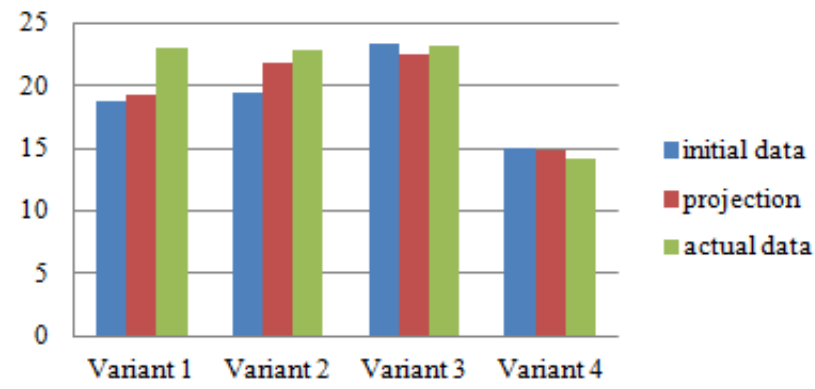

Fig. 4.3. Assessment of population structure. The proportion of population older than working age.

In the first and second groups of scenarios decline in the working-age population was forecasted by an average of $1.9 \%$ and thus increase the number of persons over the working age from 0.6 to $2.3 \%$. On the contrary, the third and the fourth scenario groups forecasted an increase in the number of working age people by an average of $0.1-1.4 \%$, and reduced the number of persons over the working age from 0.1 to $0.8 \%$. Also calculations of the second, third and fourth scenario groups do not take into account the increase in the number of young people as a result of an increasing fertility trend. In particular, the forecast has shown the decline in the proportion of this age group in the population by $0.3 \%$, while the actual increase goes up to $1.4 \%$. 
The migration processes that occurred in the study period had largely determined the deformation of forecasting scenarios for prospective population. Increase in population due to migration is mostly characteristic for Cherepovets $(2.9 \%)$, Petrozavodsk $(3.9 \%)$, Kaliningrad (4.2\%), Pskov (2.5\%), Veliky Novgorod (1\%) and small town in Leningrad region $(2.6 \%)$. Promoting the potential movement of the population from areas with adverse living conditions to the southern part of the Federal District has led to structural changes in the population of Kaliningrad, Pskov, Novgorod and small town in Leningrad region [17]. And also this has led to an increase in the demographic burden on the working population. In Cherepovets and Petrozavodsk in the period under review there was a population growth due to intra-regional migration.

Prospective population forecasting is largely determined by the development (stagnation) of town planning sector [18]. In many ways, occurred deformations of forecasting scenarios for prospective population are due to the transformations of the cityforming industry.

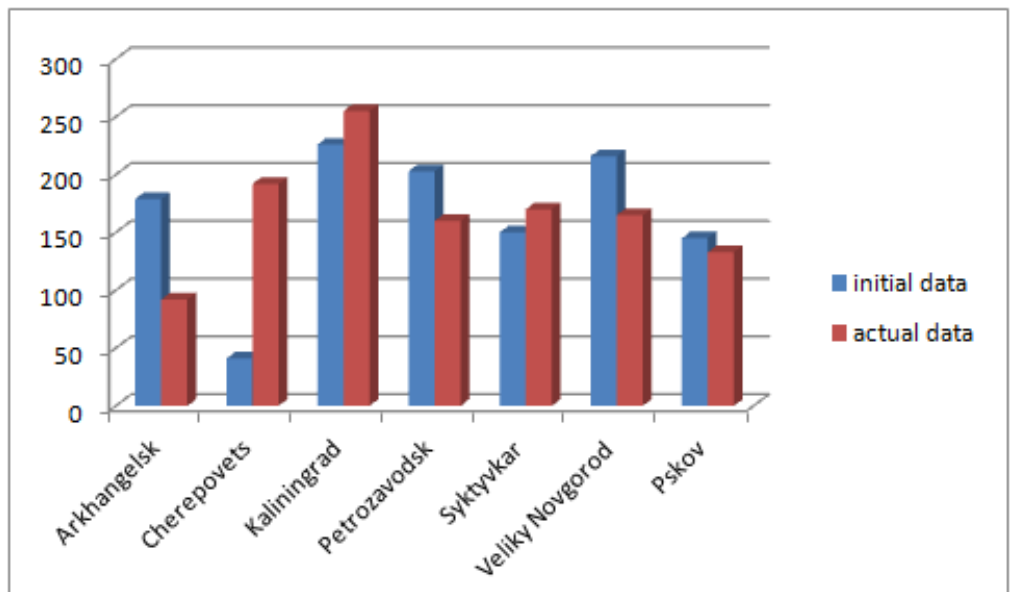

Fig. 5. The number of operating manufacturing industries in the considered large and big cities.

Describing the situation in Cherepovets it can be noted that in the period under review the decisive role in the economy of the city is preserved after large enterprises of ferrous metallurgy and chemistry. The forecasted decline of population has been based on the competitiveness analysis of specialized enterprises products, the revealed decrease in demand and reduction in production capacity [19]. At the same time it was necessary to take into account the attractiveness of the city for immigrants from areas of the Vologda and neighboring regions while determining the prospective population of Cherepovets in the master plan. A similar situation can be seen in Petrozavodsk: the resumption of largescale enterprises in the city has increased its attractiveness to migrants from areas of the Republic of Karelia.

For any decisionmaking on town-planning, including determining the prospective population projected area, the organization of social systems, transport and engineering infrastructure, it is necessary to have adequate, optimal or full information. General plans of these cities in the North-West Federal District of Russia have been developed and approved in the absence of strategies for socio-economic development at the regional level (with the exception of Syktyvkar) and direct federal district. Also we revealed the fact of development of general plans of the researched cities before schemes of territorial planning of the Russian Federation were adjusted.

These features of the preparation of territorial planning documents determined the impossibility of the realization of design decisions on the development of town-planning 
sector of the particular cities located in the northern part of the Federal District. These cities are characterized by the need for more intensive state intervention in the economic process of reproduction. Particularly, analysis of design decisions on Arkhangelsk General Plan has revealed that the prospective population of the city is determined taking into account the implementation of the Arctic development scenarios.

An important direction of Arkhangelsk urban development is associated with the creation of a resource center for shelf development: the inclusion of Arkhangelsk into mining on the Arctic shelf [20]. The decision of Russia's massive strategic objectives on the development of northern territories and the Arctic is impossible without intellectual, informational, cadre, research and education provision [20]. The development of educational and research components, service-oriented companies involved in the extraction of natural resources on the Arctic shelf, in accordance with the general plan of the city involves the creation of a campus at the Northern Arctic Federal University [3].

Initiative proposal had transformed into the creation of the Northern Arctic Federal University on the basis of three institutions of higher education located in Arkhangelsk, and largely determined the deformation of forecasting scenario for prospective population towards its actual growth.

\section{Conclusions}

Adaptation to the processes identified in this study will require accelerated development of social infrastructure, oriented to the needs of the respective age groups at deformations scenario forecasting prospective population towards its actual growth, or appropriate adjustment promising power of social infrastructure in the actual recession.

Identified deformations of forecasting scenario for prospective population contributed to the decisions of certain municipalities to update solutions of territorial planning documents before their design life. In the present conditions as an alternative of finding effective tools for urban development borrowing of scenario forecasting method can considered while developing strategic planning documents, urban planning and establishing design decisions in the territorial planning documents corresponding to each scenario development.

\section{References}

1. T. Kramkova, Property relations in the RF 4, 41 (2013)

2. V. Masch, Journal of Urban Management 1 (2), 6 (2012)

3. The General plan of Arkhangelsk, URL: http://www.arhcity.ru

4. The General plan of Kaliningrad, URL: http://www.klgd.ru

5. The General plan of Cherepovets, URL: http://vologda.news-city.info

6. The General plan of Petrozavodsk, URL: http://www.petrozavodsk-mo.ru

7. The General plan of Veliky Novgorod, URL: http://www.adm.nov.ru

8. The General plan of Pskov, URL: http://ugd.pskovadmin.ru

9. The General plan of Syktyvkar, URL: http://сыктывкар.pф

10. The General plan of Borovichi, URL: http://www.boradmin.ru

11. The General plan of Velikie Luki, URL: http://www.velikieluki.ru

12. The General plan of Vyborg, URL: http://www.city.vbg.ru

13. The General plan of Gatchina, URL: http://www.gatchina-meria.ru

14. Federal state statistics service, URL:http://www.gks.ru 
15. European Charter for Regional, URL: http://docs.cntd.ru

16. J. Poot, S. Pawar, Journal of Urban Management 2 (1), 5 (2013)

17. Strategy for Socio-Economic Development of the North-West Federal District until 2020, URL: http://docs.cntd.ru

18. P. Janež, M. Bogataj, S. Drobne, GV. J. 60, 646 (2016)

19. Cherepovets city's development strategy until 2022, URL: http://ia-cher.ru

20. Strategy for Socio-Economic Development of Arkhangelsk for the period until 2020, URL: http://www.arhcity.ru 